\title{
PENGEMBANGAN PERANGKAT PEMBELAJARAN MODEL INKUIRI TERBIMBING MIND MAPPING UNTUK MENINGKATKAN HASIL BELAJAR SISWA PADA MATERI HIDROLISIS GARAM
}

\author{
Luthfi Faza Afina Riza Walida ${ }^{1)}$ Rudiana Agustini ${ }^{2)}$, Tukiran ${ }^{2)}$ \\ ${ }^{1)}$ Program Studi Pendidikan Sains, Universitas Negeri Surabaya \\ 2) Dosen Program Studi Pendidikan Sains, Universitas Negeri Surabaya \\ Email: afina_faza@rocketmail.com
}

\begin{abstract}
Abstrak: Penelitian ini bertujuan mengembangkan perangkat pembelajaran kimia berorientasi model inkuiri terbimbing dengan strategi mind mapping yang valid, praktis dan efektif. Jenis penelitian yang dilakukan adalah penelitian pengembangan dengan model Research \& Development ( $\mathrm{R} \& \mathrm{D})$. Perangkat pembelajaran diujikan terhadap siswa kelas XI SMA Negeri 1 Tuban Tahun Pelajaran 2014/2015 pada materi hidrolisis garam. Hasil penelitian menunjukkan: (1) validitas teoritis terhadap rencana pelaksanaan pembelajaran, buku ajar siswa, lembar kegiatan siswa dan tes hasil belajar berkategori sangat baik; (2) keterlaksanaan rencana pelaksanaan pembelajaran berkategori baik; (3) aktivitas siswa menunjukkan nilai tertinggi pada kegiatan membuat rumusan masalah, membuat hipotesis sementara, mengumpulkan data dan berdiskusi dengan teman; (4) keterbacaan Buku Ajar Siswa (BAS) dan Lembar Kegiatan Siswa (LKS) mudah dipahami oleh siswa (5) seluruh siswa mencapai ketuntasan hasil belajar dengan nilai tinggi $(0,9)$; dan (6) respon siswa baik terhadap proses pembelajaran. Berdasarkan hasil penelitian ini, dapat disimpulkan bahwa perangkat pembelajaran kimia SMA menggunakan model inkuri terbimbing dengan strategi mind mapping pada materi hidrolisis garam layak sehingga dapat digunakan dalam pembelajaran.
\end{abstract}

Kata Kunci: inkuiri terbimbing, pengembangan perangkat pembelajaran, strategi mind mapping.

\section{PENDAHULUAN}

Pembelajaran menurut kurikulum 2013 adalah pembelajaran kompetensi dengan memperkuat proses pembelajaran dan penilaian autentik untuk mencapai kompetensi sikap, pengetahuan dan keterampilan. Penguatan proses pembelajaran dilakukan melalui pendekatan saintifik, yaitu pembelajaran yang mendorong siswa lebih mampu dalam mengamati, menanya, mencoba/mengumpulkan data, mengasosiasi/menalar, dan mengomunikasikan. 
Kenyataan yang ada saat ini, dalam pembelajaran di sekolah yang ada di Indonesia sebagian besar masih berpusat pada guru (teacher centered). Pada saat pembelajaran, guru mendominasi proses pembelajaran dan kurang melibatkan siswa. Hal ini menunjukkan bahwa dalam proses sains hanya terbatas pada transfer ilmu pengetahuan dari guru ke siswa, sehingga siswa kurang dilibatkan (Laila, 2014).

Salah satu model pembelajaran yang sesuai dengan pembelajaran kurikulum 2013 adalah pembelajaran berbasis penelitian (inquiry learning). Model ini menekankan pada proses pencarian pengetahuan dari pada transfer pengetahuan, siswa dipandang sebagai subjek belajar yang perlu dilibatkan secara aktif dalam proses pembelajaran, guru hanyalah seorang fasilitator yang membimbing dan mengkoordinasikan kegiatan belajar. Proses pembelajaran yang menggunakan model inkuiri menuntut keterlibatan secara maksimal seluruh kemampuan siswa untuk mencari dan menyelidiki secara matematis, kritis dan logis terhadap sebuah fenomena sehingga dapat menemukan apa yang diinginkan (Sigit, 2013). Siswa juga mampu menemukan konsepnya sendiri guna meningkatkan hasil belajarnya.

Adapun salah satu strategi pembelajaran yaitu strategi mind mapping merupakan cara termudah untuk menempatkan informasi ke dalam otak dan mengambil informasi ke luar otak (Buzan, 2012). Pembelajaran dengan strategi mind mapping dapat membantu siswa dalam merencanakan, berkomunikasi, menjadi lebih kreatif, menghemat waktu, menyelesaikan masalah, memusatkan perhatian, serta mengingat dengan baik. Pembelajaran dengan menggunakan strategi mind mapping ini diharapkan siswa juga mampu meningkatkan hasil belajarnya.

Proses pembelajaran yang ada di kelas mengharuskan siswa menerima dan mengolah banyak informasi. Siswa harus mencatat banyak hal penting dan di saat yang sama mereka harus mengingat informasi tersebut untuk digunakan (recall) kembali. Long \& Carlson (2011) menyatakan kesulitan siswa terletak pada kemampuan membuat catatan dan menentukan hubungan antar konsep-konsep. Kiat yang digunakan guru untuk mengatasi masalah sebaiknya dengan menerapkan strategi yang dapat membekali siswa dengan keterampilan menyimpan informasi yang diterima dalam memori jangka panjang. Kesulitas memproses dan mengorganisasi informasi ataupun materi pelajaran di sekolah dapat diatasi dengan menggunakan strategi tertentu, salah satunya adalah menggunakan mind mapping.

Proses pembelajaran dengan inkuiri terbimbing lebih menekankan pada proses mencari dan menemukan akan tetapi, kurang mengarahkan siswa pada dokumentasi materi. Mind mapping mampu membantu siswa dalam melakukan dokumentasi materi. Mind mapping merupakan salah cara mencatat yang kreatif, efektif dan memetakan pikiran secara menarik dan mudah. 
Hidrolisis garam merupakan salah satu materi pokok dalam pembelajaran Kimia yang ada di Sekolah Menengah Atas (SMA). Konsep-konsep yang ada dalam materi pokok hidrolisis garam yang bersifat abstrak akan lebih mudah dipahami oleh siswa melalui suatu kegiatan percobaan dalam pembelajaran Kimia di kelas. Salah satu model pembelajaran yang sesuai dengan karakterisktik materi pokok hidrolisis garam adalah model pembelajaran inkuiri. Model pembelajaran inkuiri terbimbing menekankan penemuan pengetahuan secara aktif yang dilakukan oleh siswa. Siswa dituntut untuk mampu merumuskan masalah, mengajukan hipotesis, mengumpulkan data, menguji hipotesis dan merumuskan kesimpulan. Strategi mind mapping juga digunakan untuk membantu siswa dalam mengingat materi hidrolisis garam yang telah didapatkan oleh siswa, sehingga siswa juga dilatihkan dalam membuat mind mapping khususnya pada materi hidrolisis garam.

Berdasarkan hasil wawancara dengan guru kimia kelas XI SMA Negeri 1 Tuban, salah satu materi yang dianggap sulit oleh siswa adalah materi hidrolisis garam. Hal ini didukung dengan hasil angket pra penelitian yang dilakukan di SMA Negeri 1 Tuban di kelas XI IPA menunjukkan sebanyak 64,51\% siswa menyatakan sulit memahami materi Hidrolisis Garam. Materi hidrolisis garam terdiri dari konsep-konsep yang berkaitan dengan senyawa-senyawa yang mengalami hidrolisis sebagian, hidrolisis total dan senyawa yang tidak mengalami hidrolisis. Karakteristik materi ini adalah dilengkapi dengan perhitunganperhitungan berkaitan dengan penentuan tetapan hidrolisis dan dilengkapi dengan percobaan yang akan membantu siswa untuk memahami materi ini.

Berdasarkan uraian di atas, peneliti tertarik untuk mengembangkan suatu perangkat pembelajaran yang menggunakan model pembelajaran inkuiri terbimbing yang disertai dengan strategi mind mapping pada materi hidrolisis garam. Tujuan dari penelitian ini antara lain: mendeskripsikan validitas teoritis perangkat pembelajaran (RPP, Buku Ajar Siswa, Lembar Kegiatan Siswa dan Tes Hasil Belajar, mendeskripsikan kepraktisan perangkat pembelajaran yang ditinjau dari keterlaksanaan RPP, aktivitas siswa, dan kendala atau hambatan, serta mendeskripsikan keefektifan perangkat pembelajaran ditinjau dari keterbacaan, ketuntasan hasil belajar, dan respon siswa.

\section{METODE}

Jenis penelitian ini merupakan penelitian Research and Development (R\&D). Perangkat pembelajaran yang dikembangkan meliputi: Rencana Pelaksanaan Pembelajaran (RPP), Buku Ajar Siswa (BAS), Lembar Kegiatan Siswa (LKS) serta Tes Hasil Belajar (THB). Perangkat tersebut diterapkan pada 30 siswa kelas XI SMA Negeri 1 Tuban. Model pengembangan R\&D yang dikemukakan (Sugiyono, 2011) terdapat sepuluh langkah pengembangan. Namun, karena 
penelitian ini hanya untuk ujicoba kelayakan maka langkah pengembangan metode $R \& D$ terdiri dari tujuh tahap antara lain: potensi masalah, pengumpulan data, desain produk, validasi desain, ujicoba terbatas, revisi produk dan uji coba lapang. Teknik pengumpulan data yang digunakan dapat digolongkan menjadi: (1) validasi, (2) observasi atau pengamatan, (3) metode angket, dan (4) metode tes. Data yang telah terkumpul dianalisis secara deskriptif kuantitatif.

\section{HASIL DAN PEMBAHASAN}

\section{a. Validasi Perangkat Pembelajaran}

Hasil validasi terhadap perangkat pembelajaran yang meliputi RPP, BAS, LKS dan THB dapat dilihat pada tabel 1.

Tabel 1.1 Hasil Validasi Perangkat Pembelajaran

\begin{tabular}{|l|l|l|l|}
\hline No. & Perangkat & $\begin{array}{l}\text { Presentase } \\
(\%)\end{array}$ & Keterangan \\
\hline 1. & RPP & 94,2 & Sangat Layak \\
\hline 2. & BAS & 85,5 & \\
\hline 3. & LKS & 96,6 & \\
\cline { 1 - 2 } 4. & $\begin{array}{l}\text { Instrument } \\
\text { THB: } \\
\text { a. Validasi Isi } \\
\text { b.Validasi } \\
\text { Bahasa dan } \\
\text { Penulisan } \\
\text { Soal }\end{array}$ & 96,7 & \\
\hline
\end{tabular}

Berdasarkan data pada Tabel 1.1 maka perangkat pembelajaran dapat digunakan dengan melakukan revisi dan saran dari validator. Perangkat pembelajaran yang dkembangkan dapat digunakan oleh guru sebagai panduan dalam proses pembelajaran.

\section{b. Keterlaksanaan Pembelajran dan Aktivitas Siswa}

Hasil pengamatan terhadap keterlaksanaan pembelajaran berorientasi inkuiri terbimbing dengan strategi mind mapping pada uji coba terbatas diamati dengan instrumen lembar pengamatan keterlaksanaan RPP. Jumlah pengamat keterlaksanaan pembelajaran ini adalah 2 orang. Aspek yang diamati meliputi pembukaan, kegiatan inti, penutup, dan suasana kelas. Hasil pengamatan keterlaksanaan RPP dapat dilihat pada Tabel 1.2 
Tabel 1.2 Hasil Pengamatan Keterlaksanaan RPP

\begin{tabular}{|c|c|c|c|c|c|}
\hline \multirow{2}{*}{$\begin{array}{c}\text { Jumlah Aspek yang } \\
\text { Dinilai }\end{array}$} & \multicolumn{3}{|c|}{$\begin{array}{c}\text { Rata-Rata Skor } \\
\text { Setiap Pertemuan }\end{array}$} & \multirow{2}{*}{$\begin{array}{l}\text { Rata- } \\
\text { rata }\end{array}$} & \multirow[t]{2}{*}{ Keterangan. } \\
\hline & P1 & P2 & P3 & & \\
\hline 22 & 3,64 & 3,59 & 3,68 & 3,64 & Baik \\
\hline$\%$ & 90,91 & 89,77 & 92,05 & 90,91 & $\begin{array}{l}\text { Terlaksana sangat } \\
\text { baik }\end{array}$ \\
\hline Reliabilitas & \multicolumn{5}{|l|}{98,33} \\
\hline
\end{tabular}

Keterangan. P1: pertemuan I; P2: pertemuan II; P3: pertemuan III.

Berdasarkan Tabel 2 dapat dilihat bahwa berdasarkan hasil pengamatan observer, rata-rata presentase keterlaksanaan pembelajaran yang meliputi kegiatan pendahuluan, kegiatan inti, penutup dan suasana kelas terlaksana dengan baik. Aktivitas siswa selama kegiatan pembelajaran berlangsung diamati oleh 2 orang pengamat dengan menggunakan lembar pengamatan aktivitas siswa. Hasil pengamatan aktivitasmenunjukkan bahwa frekuensi aktivitas siswa tertinggi adalah membuat rumusan masalah, membuat hipotesis sementara, mengumpulkan data dan berdiskusi dengan teman kelompok. Aktivitas yang paling jarang dimunculkan oleh siswa atau rendah frekuensinya adalah menyampaikan pendapat dengan presentase $82,5 \%$.

\section{c. Keterbacaan Buku Ajar Siswa (BAS) dan LKS}

Keterbacaan Buku Ajar Siswa (BAS), memberikan gambaran kemudahan atau kesulitan siswa dalam memahami isi dari Buku Ajar Siswa. Data yang disajikan pada Tabel 4 menunjukkan bahwa rata-rata presentase sebesar 96,46\%. Buku Ajar Siswa berkategori mudah dipahami oleh siswa. Secara ringkas keterbacaan BAS dapat dilihat pada Tabel 1.3.

Tabel 1.3 Keterbacaan Buku Ajar Siswa

\begin{tabular}{|l|l|l|l|}
\hline No & \multicolumn{1}{|c|}{ Permyataan } & \multicolumn{1}{|c|}{$\begin{array}{c}\text { Jumlah } \\
\text { Skor }\end{array}$} & $\begin{array}{c}\text { Presentase } \\
(\%)\end{array}$ \\
\hline 1 & $\begin{array}{l}\text { Saya senang dan tidak bosan menggunakan } \\
\text { BAS. }\end{array}$ & 116 & 96,67 \\
\hline 2 & $\begin{array}{l}\text { BAS ini mudah dipahami karena kalimatnya } \\
\text { tidak terlalu panjang }\end{array}$ & 117 & 97,50 \\
\hline 3 & $\begin{array}{l}\text { Saya mudah memahami kata - kata dalam } \\
\text { BAS ini. }\end{array}$ & 115 & 95,83 \\
\hline 4 & $\begin{array}{l}\text { BAS siswa ini menggunakan bahasa yang } \\
\text { baku namun tetap mudah dipahami oleh saya. }\end{array}$ & 113 & 94,17 \\
\hline 5 & $\begin{array}{l}\text { Struktur kalimat yang digunakan mudah saya } \\
\text { pahami. }\end{array}$ & 116 & 96,67 \\
\hline 6 & Pemahaman terhadap pesan atau informasi. & 116 & 96,67 \\
\hline 7 & Konsistensi penggunaan istilah & 118 & 98,33 \\
\hline 8 & Konsistensi penggunaan simbol. & 115 & 95,83 \\
\hline
\end{tabular}


Data hasil keterbacaan Lembar Kegiatan Siswa (LKS) memberikan gambaran kemudahan atau kesulitan siswa dalam memahami isi dari Lembar Kegiatan Siswa. Data yang disajikan pada Tabel 1.4 menunjukkan bahwa rata-rata presentase sebesar 96,77\%. Lembar Kegiatan Siswa berkategori mudah dipahami oleh siswa.

Tabel 1.4 Keterbacaan Lembar Kegiatan Siswa

\begin{tabular}{|l|l|l|l|}
\hline No & \multicolumn{1}{|c|}{ Pernyataan } & \multicolumn{1}{|c|}{$\begin{array}{c}\text { Jumlah } \\
\text { Skor }\end{array}$} & $\begin{array}{c}\text { Presentase } \\
(\%)\end{array}$ \\
\hline 1 & $\begin{array}{l}\text { Saya senang dan tidak bosan menggunakan } \\
\text { LKS }\end{array}$ & 114 & 95,00 \\
\hline 2 & $\begin{array}{l}\text { LKS ini mudah dipahami karena } \\
\text { kalimatnya tidak terlalu panjang }\end{array}$ & 119 & 99,17 \\
\hline 3 & $\begin{array}{l}\text { Saya mudah memahami kata - kata dalam } \\
\text { LKS ini }\end{array}$ & 114 & 95,00 \\
\hline 4 & $\begin{array}{l}\text { LKS ini menggunakan bahasa yang baku } \\
\text { namun tetap mudah dipahami oleh saya. }\end{array}$ & 113 & 94,17 \\
\hline 5 & $\begin{array}{l}\text { Struktur kalimat yang digunakan mudah } \\
\text { saya pahami. }\end{array}$ & 118 & 98,33 \\
\hline 6 & $\begin{array}{l}\text { Pemahaman terhadap pesan atau informasi. } \\
\text { Konsistensi penggunaan istilah }\end{array}$ & 118 & 98,33 \\
\hline 7 & Konsistensi penggunaan simbol. & 115 & 98,33 \\
\hline 8 & & 95,83 \\
\hline
\end{tabular}

\section{d. Hasil Belajar}

Hasil belajar dalam penelitian ini dibagi menjadi 3 aspek, yaitu: aspek pengetahuan, aspek keterampilan dan aspek sikap. Aspek pengetahuan diases dengan menggunakan tes pengetahuan. Aspek Sikap diamati dengan lembar pengamatan adalah sikap jujur. Pengamat melakukan pengamatan pada setiap pertemuan. Ketuntasan aspek sikap ditentukan dengan nilai modus untuk masingmasing siswa. Sedangkan penilaian keterampilan dilakukan dengan lembar pengamat keterampilan siswa yang meliputi menggunakan pipet, menggunakan kertas lakmus, menggunakan kertas indikator universal, pencatatan data, menganalisis, dan membuat kesimpulan. Ketuntasan hasil belajar siswa dapat dilihat pada Gambar 1.1. 


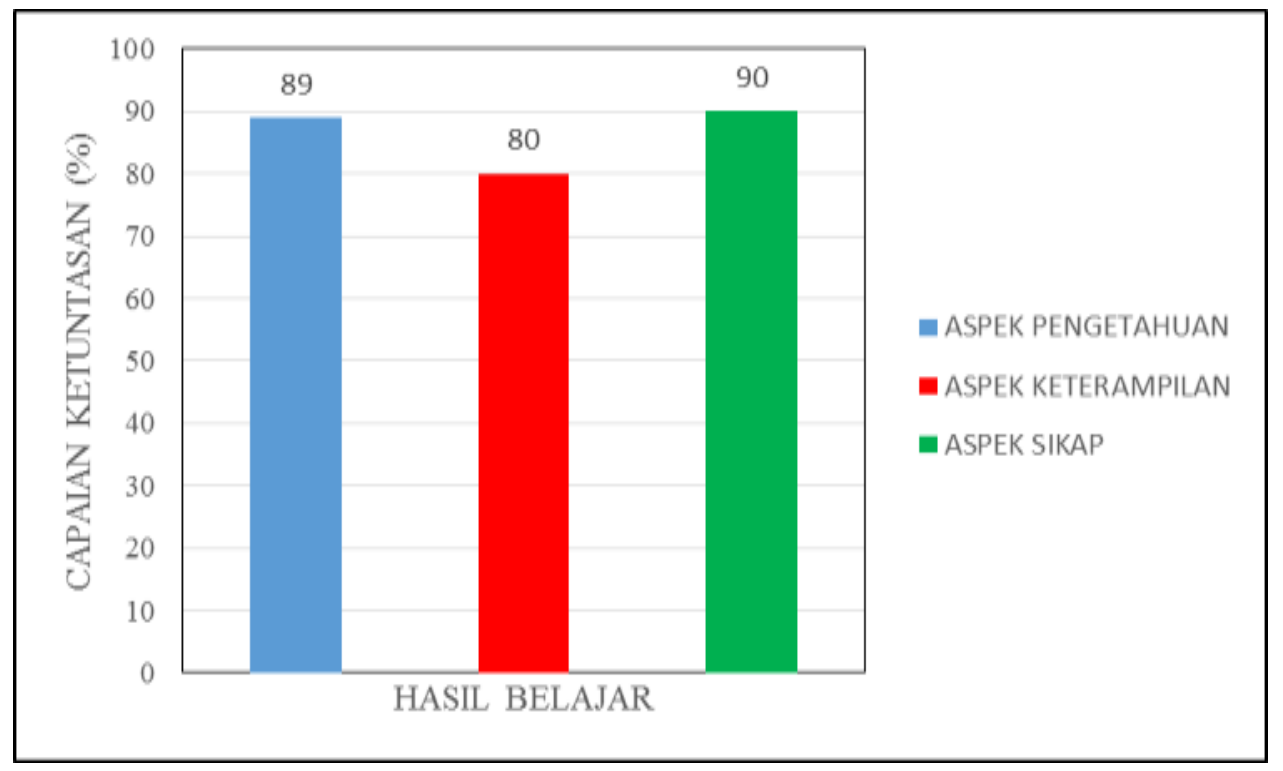

Gambar 1.1 Ketuntasan klasikan hasil belajar siswa

Pada Gambar 1.1 dapat dilihat bahwa pembelajaran inkuiri terbimbing dengan strategi mind mapping dapat memberikan kontribusi positif terhadap pengetahuan siswa. Hal ini terbukti dari hampir semua siswa tuntas dalam aspek pengetahuan (89\%). Model pembelajaran inkuiri terbimbing juga berkontribusi pada aspek pertumbuhan sikap siswa. Ketuntasan hasil belajar sikap mencapai 90\% setelah mendapatkan pembelajaran inkuiri terbimbing dengan mind mapping. Hal ini karena dalam proses inkuri terbimbing, siswa mendapat bimbingan sehingga memperoleh pengetahuan melalui pengamatan langsung dan mendorong sikap ilmiah siswa. Sikap ilmiah merupakan sikap-sikap yang seharusnya dimiliki oleh ilmuwan dalam melakukan tugasnya untuk mempelajari, meneruskan, menolak atau menerima serta merubah atau menambah. Salah satu sikap ilmiah yang harus dimiliki oleh siswa ketika berperan sebagai ilmuwan adalah sikap jujur (Juhantika, 2012). Hal ini menunjukkan dengan pembelajaran berorientasi inkuiri terbimbing mampu menunjukkan bahwa sikap jujur yang diamati oleh pengamat dalam penelitian ini menunjukkan hasil yang sangat baik.

Keterampilan yang diamati oleh pengamat merupakan keterampilan yang dilakukan siswa selama melakukan percobaan. Gambar 1.1 menunjukkan bahwa $80 \%$ hasil belajar siswa aspek keterampilan dinayatakan tuntas. Hal ini kaerna pembelajaran inkuiri menitik beratkan pada dua aspek, yaitu sains sebagai proses dan sains sebagai produk. Model pembelajaran inkuiri ditekankan pada proses sains dan mengembangkan keterampilan ilmiah. Siswa dilatih membuat prediksiprediksi, melakukan pengamatan, dan merumuskan kesimpulan. Menurut Jabot (2003) pengajaran berdasarkan inkuiri adalah sedapat mungkin menciptakan siswa untuk aktif layaknya seorang ilmuwan. Hal ini juga sesuai dengan teori belajar 
dari Piaget perkembangan kognitif sebagian besar ditentukan oleh manipulasi dan interaksi aktif anak dengan lingkunganya (Trianto, 2007). Oleh karena itu, dengan model berorientasi inkuiri terbimbing ini siswa dilatihkan untuk mampu melakukan keterampilan ilmiah melalui kegiatan percobaan yang diharapkan mampu meningkatkan hasil belajar siswa yang meliputi aspek pengetahuan, sikap, dan keterampilan.

\section{PENUTUP}

Berdasarkan hasil analisis data dan pembahasan dapat disimpulkan bahwa perangkat pembelajaran yang dikembangkan telah memenuhi syarat validitas, kepraktisan, keefektifan sehingga layak digunakan pada proses pembelajaran. Pembelajaran berorientasi inkuiri terbimbing disarankan untuk digunakan pada materi pelajaran kimia lainnya, khususnya materi dengan karakteristik yang dilengkapi dengan percobaan. Pembelajaran yang berorientasi inkuiri terbimbing yang dilengkapi dengan kegiatan percobaan diperlukan ketersediaan alat dan bahan yang memadahi sehingga mendukung proses pembelajaran.

\section{REFERENSI}

Buzan, 2012. The Mind Map Book (Memahami Peta Pikiran). Batam: Interaksara. Puspita, L \& Suciati. 2014. Pengaruh Model Problem Based Learning dengan Metode Eksperimen Disertai Teknik Concept Map dan Mind Map terhadap Prestasi Belajar Biologi ditinjau dari Motivasi Belajar dan Aktivitas Belajar Siswa". Jurnal Inkuiri, 3(1), 85 - 95.

Riduwan. 2011. Dasar - Dasar Statistika. Bandung: Alfabeta.

Slavin, R.E 2011. Psikologi Pendidikan Teori dan Praktik. Jakarta: Indeks.

Sugiyono. 2011. Penelitian Kuantitatif dan Kualitatif dan $R \&$ D. Bandung: Alfabeta.

Suyono dan Hariyanto. 2011. Belajar dan Pembelajaran. Bandung: PT Remaja Rosdakarya.

Syukri. 1999. Kimia Dasar 2. Bandung: ITB.

Wardoyo,S.M. 2013. Pembelajaran Berbasis Riset. Jakarta: Akademia Permata.

Woolfolk, A. 2009. Educational Psychology Active Learning Edition (Bagian Pertama). Yogyakarta: Pustaka Pelajar. 